\title{
Congenital Disorder of Glycosylation Type le
}

National Cancer Institute

\section{Source}

National Cancer Institute. Congenital Disorder of Glycosylation Type le. NCI Thesaurus. Code C126871.

A congenital disorder of glycosylation sub-type caused by mutation(s) in the DPM1 gene, encoding dolichol-phosphate mannosyltransferase subunit 1. 